\title{
NEW METHOD OF CRYSTAL MATERIAL HETEROGENEITY EXAMINATION
}

\author{
L.A. Barkov, barkovla@susu.ru, \\ M.N.Samodurova, samodurovamn@susu.ru, \\ E.V.Ekk, ekkev@susu.ru, \\ Yu.S. Latfulina, latfulina174@gmail.com \\ South Ural State University, Chelyabinsk, Russian Federation
}

\begin{abstract}
A principally new method of phase heterogeneity examination based on diffractometric analysis of interference maximum integral intensity of X-ray beam reflections from microvolumes of different sizes in irradiated samples of crystal materials has been developed. Also, some quantitative relationships have been experimentally tested and theoretically justified, namely the dependence of X-ray line integral intensity on the structure of incident radiation, the size of beam projection on the surface of a sample and other survey parameters. Newly developed diffractometric survey of interference line profiles allows to reach an effective averaging in texture heterogeneities that is important for high accuracy and reliable determination of quantitative values of integral intensity. Basing on the above quantitative dependences, necessary relationships have been established to find the values of relative differences between concentrations. New method is advantageous in phase heterogeneity and crystal material porosity analysis as well as in the analysis of the efficiency of blending in multiphase powder mixtures.
\end{abstract}

Keywords: crystal material; heterogeneity; diffractometric analysis; X-ray spectroscopy; integral intensity; porosity.

\section{Introduction}

Structure heterogeneity in powder products, for example that of crystal phase and pore distribution, significantly influences their quality and physico-mechanical properties. Among the well known methods of crystal material heterogeneity examination there are metallography of polished sections and X-ray spectroscopy, both intended for qualitative evaluation of phase distribution in products. But these methods are timeconsuming and of no value when one wants to know the degree of heterogeneity or the nature of crystal phase and pore distribution in the bulk of a product.

New method of evaluation of the degree of heterogeneity based on diffractometric analysis of X-ray beam integral intensities surveyed as interference maxima of beam reflections from irradiated samples of different sizes has been developed to assess heterogeneity of phase and pore distribution in the bulk of a crystal or powder material. Thorough analysis of integral intensity dependence on the size of X-ray beam projection on the surface of a sample resulted in the equation permitting to find relative differences between phase concentrations in the samples of different sizes.
New method is mostly advantageous for quantitative evaluation of phase and pore distribution heterogeneity in crystalline, continuous and powder materials as well as for the estimation of powder blending efficiency in multi-phase mixtures. New method compares favourably with other known methods of phase analysis being simple, reliable, permitting to obtain accurate values of phase concentrations and to define the nature of phase and pore distribution both in microand macrovolumes of the samples in question.

\section{Apparatus and materials}

Experimental investigations on the application of new method of crystal material heterogeneity examination have been carried out with the X-ray apparatus "DRON-2"emitting $\mathrm{Cu}-K_{\alpha}$ and $\mathrm{Fe}-K_{\alpha}$ radiation $[1,2]$. During the experiment both the width and the height of the original beam were varying by "Soller" and collimating slits on the X-ray tube and the counter, respectively, the slits cutting the plane-parallel beam out of X-radiation.

For the experiment, single-phase powders such as calcium aluminates, $\mathrm{CaO} \mathrm{Al}_{2} \mathrm{O}_{3}-\mathrm{CA}$, $\mathrm{CaO} 2 \mathrm{Al}_{2} \mathrm{O}_{3}-\mathrm{CA}_{2}, 12 \mathrm{CaO} 7 \mathrm{Al}_{2} \mathrm{O}_{3}-\mathrm{C}_{12} \mathrm{~A}_{7}$ and pressed sintered silicon steel, $\mathrm{Fe}+6.68 \% \mathrm{Si}$, 


\section{Физическая химия и физика металлургических систем}

were used as well as multi-phase powders made of mixed single-phase powders. Before the experiment calcium aluminates had been atomized by different methods, screened and mixed with a plasticating agent to a putty state and then placed into a quartz cuvette.

Since the silicon steel containing up to 6.68 percent of silicon was extremely brittle at room temperature, the initial powder with $130-150 \mu \mathrm{m}$ particles had been prepared by atomizing the cast shaped granules in the vibrating mill. To obtain the dispersed powder fractions with less than $10 \mu \mathrm{m}$ particles, the atomized powder was sintered in the open air at $550{ }^{\circ} \mathrm{C}$ and atomized once again in the vibrating mill. From the prepared powders cylindrical samples were pressed under the pressure of $2000 \mathrm{MPa}$ and sintered in vacuum furnace at the temperature of $1100{ }^{\circ} \mathrm{C}$.

The finished samples were secured on the X-ray reflecting goniometer permitting to rotate the sample around its own axis, or the axis perpendicular to the plane of the reflected beam, or the both. Each separate crystal phase in the sample was investigated by X-ray beams with varying wave lengths, namely: $\mathrm{CA}-2.97 \AA$ and $4.67 \AA, \mathrm{CA}_{2}-3.49 \AA$ and $4.44 \AA, \mathrm{C}_{12} \mathrm{~A}_{7}-4.89 \AA$ and $2.68 \AA, \mathrm{Fe}+6.68 \% \mathrm{Si}-1.42 \AA$. To measure the values of interference maximum integral intensities, the profiles of interference lines from each phase were surveyed step-by-step at the angle interval of 0.01 degree and $10 \mathrm{sec}$ exposure at each step.

\section{Survey conditions}

Developing the new method of crystal material heterogeneity examination, the special study has been carried out to determine the influence of beam geometry and survey conditions on the magnitudes of interference maximum integral intensities. For this purpose, the survey of the samples was performed with the help of plane- parallel beam with the provided diaphragm using Bragg - Brentano focusing. "Soller" slits and collimating slits set up on the X-ray tube and the counter confined the incident and the reflected beams in width and height, respectively.

Investigations have shown that it is important to obtain rectangular beam projection with uniform distribution of incident beam energy all over the projection area on the reflecting surface of a sample, so as to increase the effectiveness of the method.

Photographs presented in Fig.1 show that survey conditions strongly influence the intensity of radiation and geometric form of beam projection.

Another important condition is that the rotation of a sample around the axis perpendicular to the plane of beam projection should be of the preset frequency, approximately $1 \mathrm{~Hz}$. Under such rotation the maximum quantity of crystallites forming the whole reciprocal lattice are exposed to the beam, that helps to increase the effectiveness of texture heterogeneity blending in samples.

It should be noted that all the survey conditions mentioned above help to improve the accuracy of quantitative evaluation of interference line integral intensities.

\section{Dependence of relative integral intensity on beam projection size}

As a result of experimental investigation, it was found that relative integral intensity of any interference line and the size of plane-parallel beam projection obeyed quadratic dependence (Fig. 2) instead of being directly proportional as many researchers thought. This dependence can be expressed by the following equation:

$$
J_{h_{i} \times b_{0}} / J_{h_{0} \times b_{0}}=\alpha\left(\frac{h_{i}}{h_{0}}\right)^{2},
$$

where $J_{h_{i} \times b_{0}}$ is the intensity of interference lines when the width $h_{i}$ of beam projection on the sample surface is varying, and $J_{h_{0} \times b_{0}}$ is the intensity of interference lines when the width $h_{0}$ of beam projection and the height $b_{0}$ have the base values.

Proportionality factor in Equation (1) is presented by the function

$$
\alpha=\alpha(\Delta h, \Delta \theta),
$$

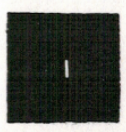

a)

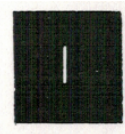

b)

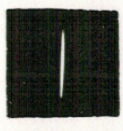

c)

Fig. 1. Photograph of the form of beam projection under different survey conditions: a - with "Soller" slits, when the size of the beam emitted by the $X$-ray tube is $0.25 \times 2 \mathrm{~mm}$ and the size of the beam received by the counter is $0.25 \times 2 \mathrm{~mm}$; $b$-with "Soller" slits, when the sizes of the beam are $0.25 \times 4 \mathrm{~mm}$ and $0.25 \times 4 \mathrm{~mm}$, respectively; c-without "Soller" slits, when the sizes of the beam are $0.25 \times 4 \mathrm{~mm}$ and $0.28 \times 8 \mathrm{~mm}$, respectively 
where $\Delta h$ is the point beam expansion of the anode spot, and $\Delta \theta$ is the interference maximum broadening.

If the anode spot point beam expansion falls within the space angle of reciprocal lattice point, then the values of function (2) are close to 1 , and if not, then $\alpha<1$.

In Fig. 3 the relative integral intensity is plotted against the beam projection size, data being obtained from the experimental investigation of polycrystalline powder samples.

\section{Results of phase heterogeneity magnitude determination}

Let us consider the application of the new method to phase heterogeneity magnitude determination by analyzing the three-phase powder mixture containing $\mathrm{CA}=15 \%, \mathrm{CA}_{2}=70 \%$ and

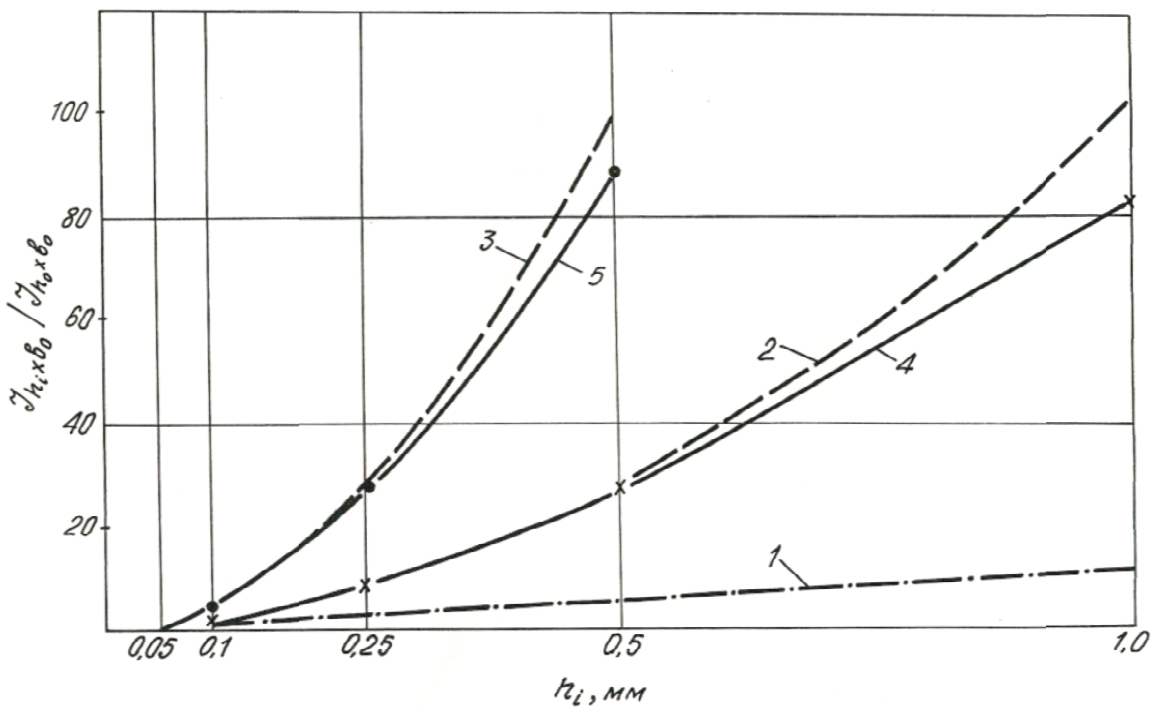

Fig. 2. Plot of the integral intensity $J_{h_{i} \times b_{0}} / J_{h_{0} \times b_{0}}$ as a function of beam projection size: 1 - taken from references [3, 4], when $h_{0}=0.1 \mathrm{~mm} ; 2$ - according to the equation (1), when $h_{0}=0.1 \mathrm{~mm} ; 3$ - according to the equation (1), when $h_{0}=0.05 \mathrm{~mm} ; 4$ - experimental, when $h_{0}=0.1 \mathrm{~mm} ; 5-$ experimental, when $h_{0}=0.05 \mathrm{~mm}$

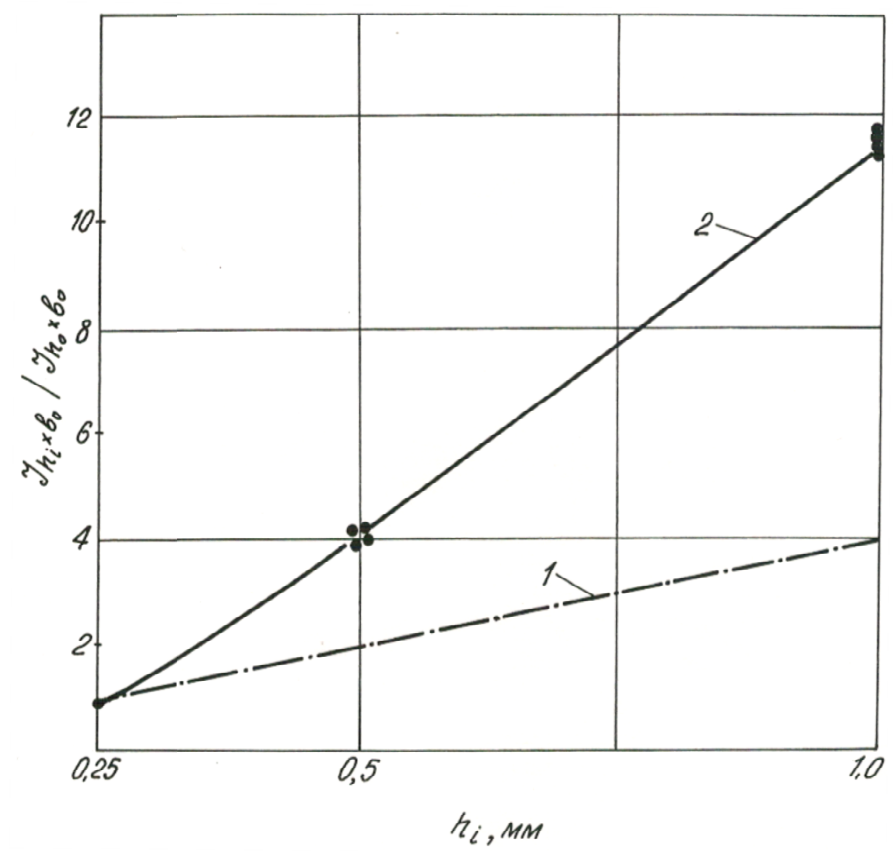

Fig. 3. Plot of the integral intensity $J_{h_{i} \times b_{0}} / J_{h_{0} \times b_{0}}$ as a function of beam projection size $h_{i}$ for single-phase powders: 1 - taken from references $[3,4] ; 2$ - experimental, when $h_{0}=0.25 \mathrm{~mm}$ 


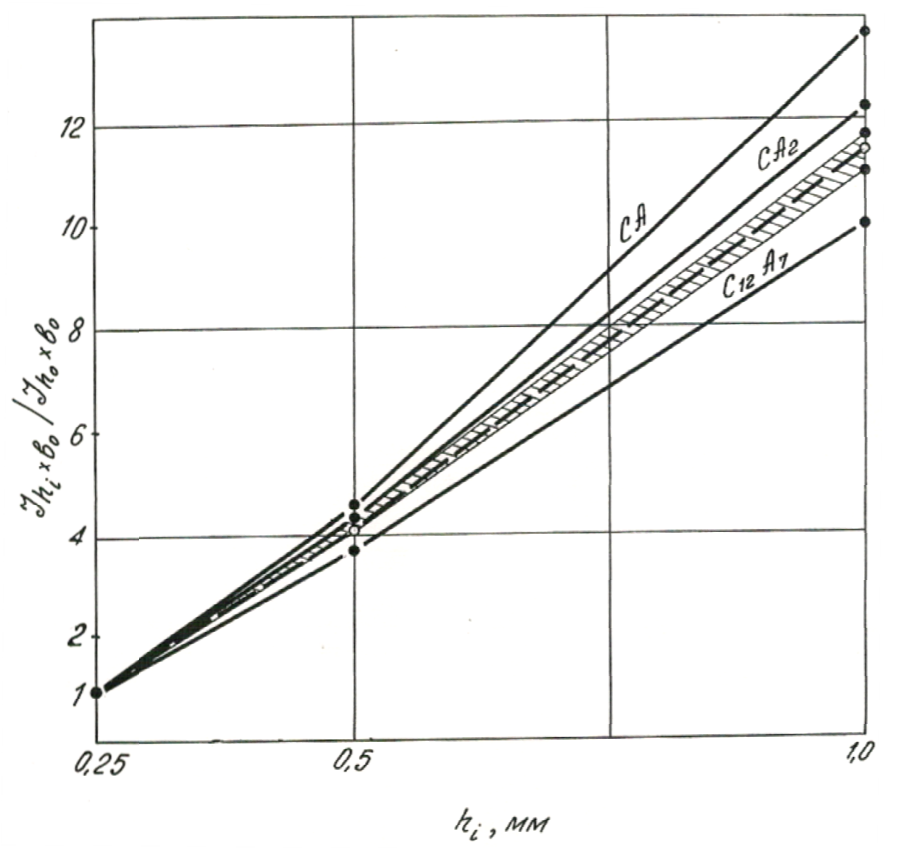

Fig. 4. Plot of the relative integral intensity $J_{h_{i} \times b_{0}} / J_{h_{0} \times b_{0}}$ as a function of beam projection size $h_{i}$ : dotted line refers to powder mixture with uniform phase distribution; shadowed area refers to powder mixture with $\pm 1 \%$ phase heterogeneity; solid line CA corresponds to phase heterogeneity of $4.80 \%$; solid line $C_{2}$ to phase heterogeneity of $5.25 \%$; solid line $C_{12} A_{7}$ to phase heterogeneity of $2.07 \%$

$\mathrm{C}_{12} \mathrm{~A}_{7}=15 \%$ calcium aluminates. In Fig. 4 the relative integral intensity of interference lines is plotted against the width of plane-parallel beam projection derived from the above powder mixture examination. The deviation of the curves marked as $\mathrm{CA}, \mathrm{CA}_{2}$ and $\mathrm{C}_{12} \mathrm{~A}_{7}$ from the base curve (dotted line) shows a non-uniform distribution of the examined crystal phases in the samples.

Using the well-known formula for the interference line intensity estimation [3] as the qualitative evaluation of phase distribution heterogeneity in powder samples and varying the width, $h_{i}$, and the base height, $b_{0}$, of beam projection on the surface of a sample, we obtain

$$
J_{h_{i} \times b_{0}}=J_{0} Q \alpha X_{i} h_{i} b_{0}
$$

where $J_{0}$ is the density of incident energy at the base height of the beam, $Q$ is the reflectivity of a sample volume unit, $X_{i}$ is the phase volume fraction exposed to radiation.

When the width of X-ray beam varies from $h_{i}$ to $h_{j}$, the relative intensity of interference lines can be expressed by the equation

$$
J_{h_{j} \times b_{0}} / J_{h_{i} \times b_{0}}=\left(\frac{h_{j}}{h_{i}}\right)^{2} \frac{X_{j}}{X_{i}}
$$

following from Equation (1). The ratio $X_{j} / X_{i}$ equals unity if the considered phase is distributed uniformly over the whole sample volume as it is in the case described by the base curve in Fig. 4 .
For the sample with non-uniform distribution of the considered phase, the Equation (4) takes the form of

$$
J_{h_{i} \times b_{0}} / J_{h_{0} \times b_{0}}=\left(\frac{h_{i}}{h_{0}}\right)^{2}\left(1+\frac{\Delta X_{i}}{X_{0}}\right)
$$

where $X_{0}$ is the average phase concentration in homogeneous sample, and $\Delta X_{i}$ is the deviation of phase concentration from its average value in heterogeneous sample.

For the given three phases in the examined powder mixture, relative deviations of concentrations from their average values have been calculated by Equation (5):

$$
\begin{aligned}
& \text { CA: } \frac{\Delta X_{i}}{X_{0}}=0.28 ; \mathrm{CA}_{2}: \frac{\Delta X_{i}}{X_{0}}=0.075 ; \\
& \mathrm{C}_{12} \mathrm{~A}_{7}: \frac{\Delta X_{i}}{X_{0}}=0.138 .
\end{aligned}
$$

\section{Results of examination} of pore distribution heterogeneity

When producing powder articles with the preset porosity, it is necessary most of all to analyze pore distribution heterogeneity. To evaluate the magnitude of pore distribution heterogeneity in samples, pressed and sintered steel powder cylinders containing up to 6.68 percent of silicon were used. Original powders had different fraction compositions which were varied by mixing the normal powder having $130-150 \mu \mathrm{m}$ fractions with different quantities of dispersed 
Porosity heterogeneity in powder samples containing $\mathrm{Fe}+\mathbf{6 . 6 8} \% \mathrm{Si}$

\begin{tabular}{|c|c|c|c|c|c|}
\hline \multirow{3}{*}{$\begin{array}{c}\text { No } \\
\text { Samples }\end{array}$} & \multirow{2}{*}{\multicolumn{2}{|c|}{ Original powder fraction composition, $\%$}} & \multirow{2}{*}{\multicolumn{2}{|c|}{$\begin{array}{l}\text { Integral intensity, pulse/s } \\
\text { Beam projection size, } \mathrm{mm}\end{array}$}} & \multirow{3}{*}{$\begin{array}{c}\text { Porosity } \\
\text { heterogeneity, } \\
\%\end{array}$} \\
\hline & & & & & \\
\hline & $130-150 \mu \mathrm{m}$ & 10 and less $\mu \mathrm{m}$ & $0.25 \times 8$ & $0.50 \times 8$ & \\
\hline 1 & 100 & 0 & 1649 & 5989 & 9.2 \\
\hline 2 & 90 & 10 & 1721 & 6431 & 6.6 \\
\hline 3 & 70 & 30 & 1769 & 6850 & 3.2 \\
\hline 4 & 50 & 50 & 1817 & 6985 & 3.9 \\
\hline \multirow[t]{2}{*}{5} & 20 & 80 & 1841 & 7047 & 4.3 \\
\hline & \multicolumn{2}{|c|}{ Cast Sample } & 3568 & 14274 & 0 \\
\hline
\end{tabular}

phase additions having less than $10 \mu \mathrm{m}$ fractions. Fraction compositions of the investigated samples are given in Table 1. For comparison, the cast base sample of the same chemical composition was used. All the results concerning the values of interference line integral intensities and pore distribution heterogeneities are also given in Table 1. Analysis of the presented results confirms that the pore distribution heterogeneity is decreasing from 9.2 to 3.2 percent when the content of fine-dispersed fractions in the powder mixture increases from 0 to 30 percent.

\section{Conclusions}

1. New X-ray method has been developed to define the heterogeneity of phases and structures in crystal materials using interference maximum integral intensities of different beam projections on the surface of a sample.

2. New technique of diffractometric survey of interference lines has been worked out allowing to achieve the effective blending of texture heterogeneity in a sample and to define qualitative integral intensity values with high degree of reliability and accuracy.

3. Mathematic relationships have been derived to find relative differences between phase concentrations in different sample volumes proceeding from $\mathrm{X}$-radiography data.

4. New method is advantageous for the evaluation of distribution heterogeneities of pores and phases in crystalline materials as well as for the analysis of the effectiveness of blending for multiphase powder mixtures.

5. No further improvement of the method is necessary to design X-ray tubes with more uniform distribution of the X-radiation energy over the projection area of the original beam.

\section{References}

1. Saltykov S.A. Stereometrische Metallographie. Leipzig, VEB Deutscher Verlag für die Grundstoffindustrie, 1974. 397 s.

2. Mikroanalyse mit Elektronen- und Ionensonden. Brummer O. (Hrsg.). Leipzig, VEB Deutscher Verlag für die Grundstoffindustrie, $1981.54 \mathrm{~s}$.

3. Umanskiy Ya.S., Skakov Yu.A., Ivanov A.I., Rastorguev A.I. Kristallografiya, rentgenografiya $i$ elektronnaya mikroskopiya [Crystallography, X-Ray Diffraction and Electron Microscopy]. Moscow, Metallurgiya Publ., 1982. 630 p.

4. Umanskiy Ya.S. Rentgenografiya metallov [X-Ray Diffraction Study of Metals]. Moscow, Metallurgiya Publ., 1960. 447 p. 


\title{
НОВЫЙ МЕТОД ИССЛЕДОВАНИЯ НЕОДНОРОДНОСТИ КРИСТАЛЛИЧЕСКОГО МАТЕРИАЛА
}

\author{
Л.А. Барков, М.Н. Самодурова, Е.В. Экк, Ю.С. Латфулина \\ Южно-Уральский государственный университет, г. Челябинск
}

\begin{abstract}
Разработан принципиально новый метод исследования фазовой неоднородности на основе дифрактометрического анализа интегральной интенсивности интерференционного максимума отражений рентгеновского луча от микрообъемов облученного образца различных размеров в кристаллических материалах. Кроме того, были проверены экспериментально и теоретически обоснованы некоторые количественные соотношения, а именно зависимость интегральной интенсивности рентгеновской линии на структуру падающего излучения, размер проекции луча на поверхность образца и другие параметры исследования. Разработанный дифрактометрический анализ профилей интерференционных линий позволяет достичь эффективного усреднения в неоднородностях текстуры, что имеет важное значение для высокой точности, надежного определения интегральной интенсивности количественных значений. На основании приведенных количественных зависимостей, были установлены необходимые соотношения для нахождения значения относительных различий между концентрациями. Новый способ полезен при анализе фазовой неоднородности и пористости кристаллического материала, а также при анализе эффективности смешивания многофазных порошковых композиций.

Ключевые слова: кристаллический материал; неоднородность; рефрактометрический анализ; рентгеновская спектроскопия; интегральная интенсивность; пористость.
\end{abstract}

\section{Лuтература}

1. Салтыков, С.А. Стереометрическая металлография / С.А. Салтыков. - М.: Металлургия, 1976. $-271 \mathrm{c}$.

2. Mikroanalyse mit Elektronen- und Ionensonden / O. Brummer (Hrsg.). - Leipzig: VEB Deutscher Verlag für die Grundstoffindustrie, 1981. - 54 s.

3. Кристаллография, рентгенография и электронная микроскопия / Я.С. Уманский, Ю.А. Скаков, А.И. Иванов, А.И. Расторгуев. - М.: Металлургия, 1982. - 630 с.

4. Уманский, Я.С. Рентгенография металлов / Я.С. Уманский. - М.: Металлургия, 1960. 447 с.

Барков Леонид Андреевич, д-р техн. наук, профессор, заместитель по научной работе руководителя НОЦ «Ресурсный центр спецметаллургии», Южно-Уральский государственный университет, г. Челябинск; barkovla@susu.ac.ru.

Самодурова Марина Николаевна, канд. техн. наук, доцент кафедры машин и технологий обработки материалов давлением, руководитель НОЦ «Ресурсный центр спецметаллургии», Южно-Уральский государственный университет, г. Челябинск; samodurovamn@susu.ru.

Экк Евгений Вальтерович, канд. техн. наук, доцент кафедры машин и технологий обработки материалов давлением, заместитель по учебной работе, Южно-Уральский государственный университет, г. Челябинск; ekkev@susu.ru.

Латфулина Юлия Сергеевна, инженер-исследователь НОЦ «Ресурсный центр спецметаллургии», Южно-Уральский государственный университет, г. Челябинск; latfulina174@gmail.com.

Поступила в редакцию 27 октября 2016 г.

\section{ОБРАЗЕЦ ЦИТИРОВАНИЯ}

New Method of Crystal Material Heterogeneity Examination / L.A. Barkov, M.N. Samodurova, E.V. Ekk, Yu.S. Latfulina // Вестник ЮУрГУ. Серия «Металлургия». - 2016. - Т. 16, № 4. - С. 23-28. DOI: $10.14529 /$ met 160403

\section{FOR CITATION}

Barkov L.A., Samodurova M.N., Ekk E.V., Latfulina Yu.S. New Method of Crystal Material Heterogeneity Examination. Bulletin of the South Ural State University. Ser. Metallurgy, 2016, vol. 16, no. 4, pp. 23-28. DOI: $10.14529 /$ met160403 